\title{
Effect of School Environment on the Development of Students' English Language Skills at Secondary School level in Khyber Pakhtunkhwa
}

\author{
Allah Noor Khan ${ }^{1}$, Shehla Sheikh², Mazhar Gul ${ }^{3}$
}

\begin{abstract}
Current study aims to perceive the institutional factors accountable for the low standard of teaching of English which may not develop effective English Language skills of the learners at public secondary level in southern districts of Khyber Pakhtunkhwa. Two main variables are focused i.e. teaching strategies and school environment. These were considered regarding the weak English Language skills of all the students of Secondary Schools session 2016-17 in Southern districts (Lakki Marwat, Bannu, Tank, D.I.Khan, Kohat, and Karak) of Khyber Pakhtunkhwa, Pakistan. The total population was 120,885 students and $1 \%$ as its sample through stratified random disproportionate sampling technique. Sample included 1208 respondents i.e. $(n=604$ students male (302urban plus 302 rural and $n=604$ female students (302 urban plus 302 rural) from schools through simple random sampling technique, following rule of thumb, Dr. John Curry (1984).Mean and Standard Deviation were used as statistical measures. The results showed that the teachers do not adopt modern teaching strategies and the tough, raucous and crowded environment was provided in the schools.
\end{abstract}

Keywords: School Environment, English Language skills, Teaching Strategies.

\section{Introduction}

English language enjoys a vital position in getting hold of knowledge. It is the responsibility of teachers to motivate students for participation in various activities pertaining to English language skills (Cole \& Feng, 2015). The National Education Policy (2009) intensely supports for both teachers and students to develop communication skills in English. Agramal (1995) considers Language as a means of conveyance of views and lack of control over it means

\footnotetext{
${ }^{1}$ Assistant Professor, Institute of Education \& Research, Gomal University D.I. Khan Email: noormarwat2@yahoo.com

${ }^{2}$ Lecturer, Institute of Education \& Research, Gomal University D.I. Khan

Email: shehlagu@yahoo.com

${ }^{3}$ M.Phil Graduate, Institute of Education \& Research, Gomal University D.I. Khan Email: maz99953@gmail.com
} 
that the thoughts are indescribable. Minkova (2001) gives English the status of the Lingua Franca of the sphere. It has substituted French in the international relations, Germany in the scientific field and Latin in the area of literature. Among five persons, one speaks English globally. It enjoys the position of an official or co-official language of forty five countries of the world (pp.3, 28-31). Four basic skills (English Language Skills) are found vital skills in English; and without theseskills, English acquisition is very difficult (Abdulwahed Ahmed Ismail, 2011).Bridget (2009) supported female students to be encouraged in their different societies and these influences the way they perform in Spoken English class. Those students, who are lacking in the English Language skills, feel anxiety that they may not get the goal in English unless they progress their competencies in English Language (Thomas, Clark \& Gioia, 1993). It is very easy to improve the language skills of secondary school students through both parents and teachers' proper assessment and feedback (Kasper \& Petrello, 1998). It is mandatory to focus on their vocabulary and grammar for the purpose of competency improvement in English because English Language is nearly impossible without rich vocabulary and grammar. Dzay \& Medina (2002) supported the use of accurate listening resources for English as it progresses listening skills and lessens the problems that pupils have when utilizing true resources.

It is important to encourage students for expressing their ideas in a proper way but it is most important to bring those ideas in written form (Shaughnessy, 1998). Teacher's feedback is essential for the enhancement of students' English language competency (Kasper \& Petrello, 1998). Both home (parents) and school (teachers) are bound and responsible to develop students' English language skills by sharing their written experiences, documentary activities, drafting as feedback, speaking, listening English programs on radio or TV in order to improve English language capabilities of students (Beaven, 1977). Teaching skills is a very important part in the English language learning and no doubt, it needs special attention. The natural properties of the written channel are permanent and characterized by logical sequences; uses a consistent set of graphic symbols and punctuation, help learners to frame their meanings and messages, which they write and ultimately create a text. Teachers have to remember that "the product is, after all, the ultimate goal: the reason that we go through the process of prewriting, drafting, revising and editing. Writing is the most difficult of all the skills. Writing skill combines verbal and motor skills. The learner has to be well versed in words and must know correct word order. Knowledge of correct spelling is also essential. There should be an organization in a logical sequence. Effective communication is also a professional standard for 
teachers in Pakistan (Ministry of Education, 2009). All the skills are interrelated and interdependent. An English teacher must have proficiency in these four skills in order to inculcate them in students effectively.

\subsection{Research Objectives}

The research focuses on the following objectives:-

1. To analyze the effect of teaching strategies in teaching English Language on the development of students' English Language skills as perceived by students at secondary level.

2. To observe school environment for improving English language skills as perceived by students at secondary level.

\subsection{Research Hypotheses}

1. There is no significant effect of teaching strategies on the development of students' language skills in English as perceived by students.

2. There is no significant effect of school environment on the development of students' language skills in English as perceived by students.

\subsection{Significance of Study}

The study is highly significant for teachers to focus on the development of students' English language standard. The result may be helpful for educational planners in formulating the policy regarding in improvement of English Language skills. The study is quite vital for the students to consider grammatical accuracy. The study is helpful for those students whose basic skills are poor. The study may prove helpful for curriculum planners to devise curriculum in such a way to ensure maximum participation of students.

\section{Literature Review}

Vocabulary is the biggest problem for English learners; they need the help of their teachers and different resources like magazines, journals and books so that their English vocabulary and writing abilities may be fruitfully improved (Stahl, 1985). Teachers may strengthen their students' writing competencies through different ways such as by assigning them creative type essay and assignments (Vygotsky, 1987).Teachers should take it as a first priority to always motivate and engage students' English language activities in school; and parents are highly liable to check the home written assignments of their children for refining their writing skills (Lee, 2012).

Kraemer (2008) emphasized that guideline alludes to a precisely arranged blend of both customary classroom direction and web based learning exercises and declared it as an inventive curricular feature that considers patterns in remote dialect instruction. Elke and Tsila (2009) displayed multisensory organized dialect (MSL) instructing techniques to remediate these learners' 
challenges in perusing, composing, and communicating in English. Students' English language skills can be improved through latest technology like using a computer by immediate correcting spelling and grammatical errors (Ghandoura, 2012; Abdulwahed Ahmed Ismail, 2009). Well-structured essays with enhanced ideas need advanced writing competency; spelling, handwriting, punctuations, rich vocabulary and grammar are various sources that improve and refine English Language and command on all these sources make a perfect writer. Writing competency may be highly developed and fully improved through brainstorming (Troia \& Graham, 2002). Story, essay and assignment writing, analyzing information and summarizing are the different means and techniques to improve English language capabilities (Persky, Daane \&Jin, 2003). Writing competency can be highly developed with the help of writing proper assignments as routine (Bridgeman \& Carlson, 1984). Espinoza, 2007; Langford, 2007; Mota (2007) considered English linguistic and socio-cultural contextual studies to gather data about those who attained higher linguistic competence in English. They had established more hours of instruction in elementary, secondary and high school; the study relates consistency and continuity that make a difference in language instruction. Muralikrishna \&Sunitha (2004) reported that human beings possess two ears and one tongue, it means that they have to listen more and speak less. Listening is a basic skill and it requires the process of receiving, interpreting and responding. The ethics say that a listener needs to show agreement with the speaker's view. Tickoo (2009) further elaborates that listening requires attention in an organized manner.

\subsection{Research Design}

\section{Research Methodology}

The study was descriptive in nature.

\subsection{Population}

All secondary schools students of six districts (Lakki Marwat, Bannu, D.I Khan, Kohat, Karak, and Tank) constituted the population of the study. There were 120,885 secondary school students in these southern districts at secondary level.

\subsection{Sample}

Stratified random sampling technique was applied following John Curry rule of thumb (1984) as cited in Yount (2006) taking sample size 1\% of the total population. The total numbers of respondents taken as sample were $(\mathrm{N}=1208)$ in which ( $n=604$ male, 302 rural and 302 urban) while $(n=604$ female; 302 rural and 302 urban). 


\subsection{Instrumentation}

Questionnaire included three parts: first part was related with demographic variable; second part dealt with teaching strategies of the teachers including 10 items based on five options "very frequently (5), frequently (4), occasionally (3), seldom (2), and never (1) while the third part was associated with school environment and it too included 10 items. Moreover, it had five responses i.e. strongly agree, agree, undecided, disagree, and strongly disagree carrying values 5, 4, 3, 2 and 1 . Total items were 20 excluding demographic items. It was made valid after processing through a group of experts for content validity and some items were deleted through this process. Reliability was determined through Cronbach Alpha which was 0.87.

\subsection{Data Collection}

The researcher collected the data from students with the help of teachers and some senior M.Phil students who were guided in this respect. The research instrument was distributed among all the 1208 students who were randomly chosen for the data collection. 1150 properly filled in copies of the tool received about $95 \%$ return rate. Data were analyzed through descriptive statistics and SPSS was used for calculating mean score.

Table 1

\section{Findings \& Discussion}

Students' Reponses about Teaching Strategies and School Environment on English Language Skills at Secondary School Level

\begin{tabular}{lll}
\hline S.N & Variables & Mean \\
\hline I & Teaching Strategies & \\
1. & Lecture method & 3.85 \\
2. & Grammar translation method & 3.78 \\
3. & Reading skill is focused in English class & 3.69 \\
4. & Writing skill is focused in English classroom & 3.58 \\
5. & Listening skill is focused & 2.75 \\
6. & Speaking skill is focused in English classroom & 2.74 \\
7. & Group work & 2.12 \\
8. & Debate/discussion & 1.80 \\
9. & Activity based learning & 1.77 \\
10. & Various sources of knowledge i.e. journals and & 1.64 \\
& novels & \\
II & School Environment & 3.85 \\
1. & Instruction in Urdu & \\
\hline
\end{tabular}




\begin{tabular}{lll}
\hline 2. & Overcrowded classes & 3.98 \\
3. & Electrical facilities & 3.60 \\
4. & Trained staff members & 3.11 \\
5. & Instruction in English & 2.56 \\
6. & Spacious rooms for group work & 2.54 \\
7. & Conducive learning environment & 2.52 \\
8. & Use of library through latest ICTs resources & 2.28 \\
9. & Offices for staff members and students' & 2.17 \\
& counselling infrastructure & \\
10. & Suitability of infrastre & 1.62 \\
\hline
\end{tabular}

Variables with mean score 1-2 was measured to be 'Minimum'; 2-3 as 'Below Average'; 3.0 as 'Average'; 3-4 as 'Beyond Average'; and 4-5 was considered to be supreme. The first variable indicated that teachers teach the students through old and traditional methods, the lecture is normally given in the English classrooms and they take the help of text books. Discussion, debate, and brainstorming are rarely used. Mostly conversation is taking place in Urdu instead of English. Grammar translation method is adopted. Basic skills i.e. writing and reading skills are focused to some extent but the listening and speaking skills are less practically practiced in English classrooms. Creative work is not focused and teacher centered role is adopted in the classrooms. Modern teaching strategies i.e. maximum participation of the students is seldom adopted. Presentation of model essays, students' exposure to various sources of knowledge i.e. journals, novels, magazines are not practiced.

The second variable showed that the environment of the school is not too much helpful for English learning. Urdu medium is spoken or both teachers and students speak in their mother tongue. The classes are overcrowded, not suitable for discussion and participatory approach or maximum participation of the students. Infrastructure wise, the school environment is not conducive; the rooms are not spacious and are not suitable for group work. No proper offices for staff; no rooms for students' counseling are available. The staff members are not properly trained in the light of modern English teaching techniques, no proper use of the library; the library is not equipped with modern English language equipment i.e. use of Information and communication technology for English learning skills and books. Electricity in the majority of the schools was provided. It was cleared from the results of the study that teachers played vital role in developing students' language competency in English. Parents-teachers meeting (PTM) was given high value because parents might share their experiences about their children language skills with the teachers. 
The results of the study are supported by Meera and Remya (2010) who reported that teachers teaching English may be proficiently sound in pedagogical skills and phonological awareness for creating creativeness among learners. Language teacher can make composition and grammar interesting and exciting through creative work. Vazalwar and Yadav (2005) concluded that environment influence reading comprehension in English. Avinashilingam and Sharma (2005) stated that students' inner urge, the competency of teachers, no physical distraction and contacts with like-minded colleagues can make students more competent to succeed in life. In this line of thinking, Dwivedi et al. (2007) recommends that favorable environment polishes academic achievement of the students.

\section{Recommendations}

The study offers following recommendations:-

1. The teachers training institutions may ensure interaction in English for teaching of English language course. The teachers may be inspired to improve English language skills of their students by following activity based learning, group work, discussion and brainstorming in English classrooms at secondary level. The direct method of teaching may be adopted for improving the English language skills at secondary level. English may be spoken in English class as a medium of instruction to polish the English language skills of learners.

2. Refresher courses may be organized for English teachers to update them with the new English teaching techniques.

3. The school may be provided with A.V. Aids i.e. computers, multimedia, tape-recorder and internet facility so that the teachers may use modern teaching techniques in English class.

4. Library usage with the latest ICT resources and separate offices for teachers for counselling need to be provided.

5. Provision of journals / novels for reading of students, debate and discussion opportunities for improving listening and speaking skills of the students in English class may be ensured.

\section{References}

Abdulwahed Ahmed Ismail, S. (2011). Exploring Students' Perceptions of ESL Writing. English Language Teaching, 4(2), 73. doi: 10.5539/elt.v4n2p73

Agramal, L. (1995). General Language Practices. New York, USA: Merrill Publishing Company. 
Avinashilingam, N. A. V., \& Sharma, G. (2005). Identification of Factors Influencing the Students' Academic Performance. Journal of Educational Research and Extension, 42(1), 25-32.

Beaven, M. (1977). Individualized goal setting, self-evaluation, and peer evaluation. In C.R. Cooper and L. Odell. Evaluating Writing (pp. 135156). Urbana, IL: National Council of Teachers of English.

Bridgeman, B., \& Carlson, S. B. (1984). Survey of academic writing tasks. Written Communication, 1, 247-280.

Bridget, O. (2009). Education. Chula Vista. Summer. 129(4), 571-573 Retrieved from http://proquest.umi.com.

Cole, J., \& Feng, J. (2015, April). Effective Strategies for Improving Writing Skills of Elementary English Language Learners. Paper presented at the Chinese American Educational Research and Development Association Annual Conference, Chicago. Retrieved from https://files.eric.ed.gov/fulltext/ED556123.pdf

Dwivedi, Y. K., Khoumbati, K., Williams, M. D., \& Lal, B. (2007). Factors affecting consumers' behavioural intention to adopt broadband in Pakistan. Transforming Government: People, Process and Policy, 1(3), 285-297.

Dzay, F., \& Medina, S. (2002). Auténtico de audio en la enseñanzade lidiomainglés (Unpublished master's dissertation). Instituto de estudios universitarios, Quintana Roo, México

Elke, S., \& Tsila, E. (2009). Linguistic intervention techniques for At-Risk English language learners. Foreign Language Annals, 42(1), 55-76.

Espinoza, L. (2007). Instrucción Escolar y suRelación con el Nivel de Competencia Lingüistica en Inglés en Estudiantes de Nuevo Ingreso a lasInstituciones de Educación Superior en Aguascalientes (Unpublished master's dissertation). Universidad Autónoma de Aguascalientes.

Ghandoura, W. A. (2012). A qualitative study of ESL college students' attitudes about computer-assisted writing classes. English Language Teaching, $5(4), 57-64$.

HEC. (2009). Higher Education Commission, Govt. of Pakistan, Islamabad. 
Kasper, L. F., \& Petrello, B. A. (1998).Responding to ESL Student Writing: The Value of a Non-judgmental Approach. Community Review, 161-178.

Kraemer, A. (2008). Engaging the foreign language learner: using hybrid instruction to bridge the language-literature gap (Ph.D. Dissertation). Michigan State University, East Lansing, MI.

Langford, P. (2007). Competencia lingüística en inglés y razonamiento verbal y español. Un estudio con estudiantes de nuevo ingreso a instituciones de educación superior en Aguascalientes en 2006. (Unpublished master's dissertation). Universidad Autónoma de Aguascalientes, México.

Lee, H. (2012). The reading response e-journal: An alternative way to engage low-achieving EFL students. Language Teaching Research, 17(1), 111131.

Meera, K. P., \& Remya, P. (2010). Effect of extensive reading and creativity on achievement in English language. E-journal of All India Association for Educational Research, 22(1), 16-22.

Ministry of Education. (2009). National Education Policy. Govt. of Pakistan, Islamabad.

Minkova, D., \& Stockwell, R. (2001).English words: History and structure: A Case Study. Asian Social Science, 8(3), 88-99.

Mota, M. (2007).Competencia lingüistica en inglés y su relación con la formación educativa y la exposición al idioma en los ámbitos escolar, extraescolar y sociofamiliar: un estudio aplicado a alumnos de nuevo ingreso a instituciones de educación superior en Aguascalientes (Unpublished master's dissertation). Universidad Autónoma de Aguascalientes.

Muralikrishna, C., \& Sunitha, M. (2004).Communication Skills for Engineers. Pearson.

Persky, H. R., Daane, M. C., \&Jin, Y. (2003).The nation's report card: Writing 2002. (NCES 2003-529) Washington, D. C: National Centre for Education Statistics, Institute of Education Sciences, U.S Department of Education.

Shaughnessy, M. P. (1988). Diving in: An introduction to basic writing. In G. Tate, E.P.J. Corbett \& N.Myers (Eds).The Writing Teacher's Sourcebook (pp. 321-326). New York: Oxford University Press. 
Stahl, S. (1985). To teach a word well: A framework for vocabulary instruction. Reading World, 24(913), 16-27.

Thomas, J. B., Clark, S. M., \& Gioia, D. A. (1993). Strategic sense making and organizational performance: Linkages among scanning, interpretation, action, and outcomes. Academy of Management Journal, 36(2), 239-270.

Tickoo, M. L. (2009). Teaching and Learning English: A Sourcebook for Teachers and Teacher-Trainers, India: Orient Blackswan Pvt Ltd.

Troia, G., \& Graham, S. (2002).The effectiveness of a highly explicit, teacherdirected strategy instruction routine: Changing the writing performance of students with learning disabilities. Journal of Learning Disabilities, 35, 290-305.

Vazalwar, C., \& Yadav, R. (2005). Tracing out the Relationship of Reading Comprehension in English with Respect to Anxiety, Socio-Economic Status and School Environment. Ram-Eesh Journal of Education, 2(1), 27-31.

Vygotsky, L. S. (1987). The Collected Works of L. S. Vygotsky: Problems of General Psychology. New York: US: Springer. doi: 10.1007/978-1-4613$1655-8$

Yount, W. (2006). Research Design and Statistical Analysis for Christian Ministry. Fort Worth, Tex.: W.R. Yount. 